\title{
INTERNAL STRUCTURE AND ENVIRONMENTAL RECONSTRUCTION OF EOCENE TRANSITIONAL FAN-DELTA DEPOSITS, MONLLOBAT-CASTIGALEU FORMATIONS, SOUTHERN PYRENEES, SPAIN
}

\section{SJOERD VAN DER MEULEN}

Department of Earth Sciences, Comparative Sedimentology Research Group, P.O. Box 80.021, 3508 TA Utrecht (The Netherlands)

(Received November 16, 1982; revised and accepted June 3, 1983)

\section{ABSTRACT}

Van der Meulen, S., 1983. Internal structure and environmental reconstruction of Eocene transitional fan-delta deposits, Monllobat-Castigaleu formations, Southern Pyrenees, Spain. Sediment. Geol., 37 : 85-112.

A detailed study has been made of a part $(500 \times 200 \times 15 \mathrm{~m})$ of the Eocene Monllobat Formation. The conglomeratic bottomset-foreset-topset build up of a small fan-delta passes into sand-and mudstone layers. Ultimately the sandstone layers wedge into the mudstone due to concave-upwards basal surfaces and convex top surfaces or due to thickening of intercalated mud layers. Sequences vary accordingly from coarsening upwards in the proximal parts to fining upwards distally. Both sequences are topped by a thin layer fining upwards.

The proximal, fan-deltaic part consists of interconnected lobes. Crescentic, transverse bars deposited gravel on a slightly inclined top. Conglomerates of the moderately inclined foreset show some imbrication. The bottomset consists of tabular cross-bedded and cross-laminated sandstone. Parallel-laminated and tabular cross-bedded sandstone layers drape rises of fine sediment in front of the fan-delta face. Continued progradation brought about truncation of these backset sediments.

Sandstone lobes of the distal part are not connected. Tabular cross-bedding and parallel lamination are the main sedimentary structures. Climbing, large-scale bedforms are prominent on top surfaces. Most of the lobes are enveloped by blue-grey mud. Layers covered by mottled mud terminate in foreset faces.

Highly energetic inflow took place from a shallow, braided stream with longitudinal bars. The low sedimentary relief caused jetflow. The high flow energy, the large grain-size range and the large quantities of sediment caused great differences from inflow models for the deltaic environment. Sedimentation was effected by flow deceleration. Expansion, inertial forces, friction or a combination of these phenomena were responsible for the deceleration. Expansion and inertial forces caused development of moderately inclined foreset faces. Due to expansion, steeply inclined foresets were formed. Sand was deposited in shallow marine water and in scour pits in continental deposits during flow deceleration caused by frictional and inertial forces. Parallel-laminated backsets connected with flat, tabular sets developed due to flow deceleration by expansion and frictional forces.

The deposits were formed in the transition zone of a fan-delta under a tropical climate with marked dry and wet periods. Wide, braided streams entered a restricted, shallow marine basin at right angles to the basin axis. Aggradation exceeded water depth. Progradation processes were influenced by large- and small-scale tectonic activity. 


\section{INTRODUCTION}

The Eocene Monllobat Formation is situated in the Southern Pyrenees, Spain (Fig. $1 \mathrm{~A}, \mathrm{~B})$; it contains a large amount of mottled mudstone (70-80\%). This mud is thought to have been deposited by meandering rivers as well as by sheetfloods in the distal parts of shallow, wide, graveliferous systems (Van der Meulen, 1982). Distally the systems also were in contact with a shallow marine basin. The continental Monllobat Formation interfingers with the marine Castigaleu Formation (Fig. 1C); The latter also consists mainly of mudstone, but there is no mottling. Further, only small amounts of conglomerate are found.

A stratigraphic interval of limited extent is described to illustrate the transition of conglomerates to sand- and mudstone. A part of the mud is mottled. For the rest blue-grey mud is found, occasionally with marine fossils. The chiefly three-dimen-
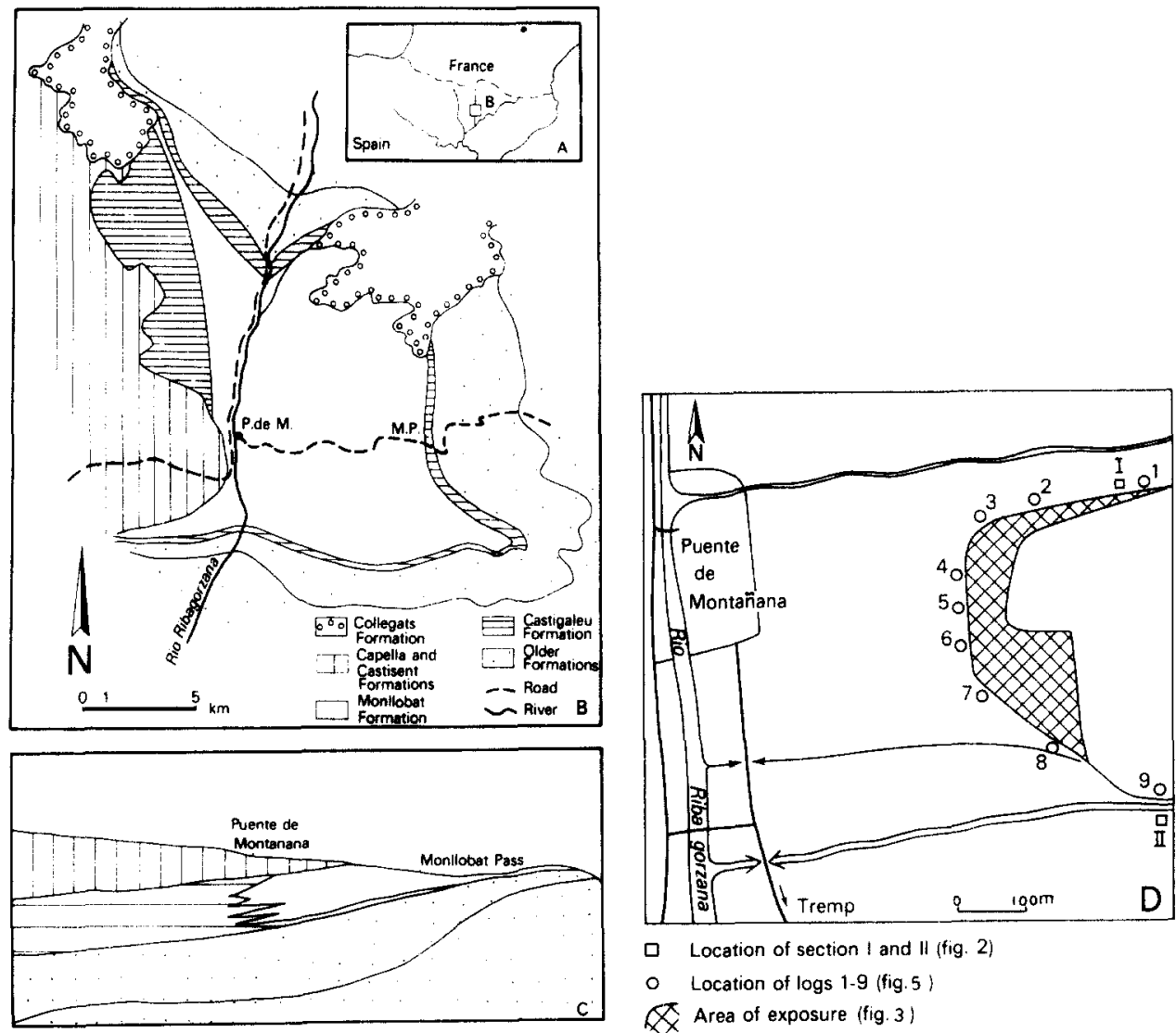

Fig. 1. Locality (A) and geological (B) map, an E-W section of the area (C) and a sketch map (D) of the investigated interval. 
sionally exposed deposits, with low tectonic dip, are situated near Puente de Montañana (Fig. 1D). The morphology of the layers, the sedimentary structures in vertical sections and the bedforms on top surfaces were studied to reconstruct rivermouth processes. Also the stratigraphic setting has been considered. The setting of the Monllobat Formation in the Tremp-Graus Basin is given by Van Eden (1970), Nijman and Nio (1975), Puigdefabregas and Van Vliet (1978) and Nijman (1981).

\section{DESCRIPTION OF THE EXPOSURES}

A three-dimensional exposure and a vertical section are described. The exposures are situated between two tributary valleys of the Ribagorzana valley (Fig. 1D). Towards the north some conglomerate and sandstone layers occur approximately on the same stratigraphic level. To the south of the interval, poorly exposed mud occurs on this level. Sections I and II (Fig. 2) also show decreasing mud contents in this direction (locations in Fig. 1D). To the south the interval is bounded by a series of vertical faults, directed from SE-NW. There is an uplift of a few metres at the southwestern side. The tectonic dip is $1-2^{\circ}$.

\section{Petrography}

Conglomerates of the proximal parts consist mainly of clastic limestone pebbles, with minor amounts of quartz pebbles. Several large blocks (up to $0.5 \mathrm{~m}$ thick) of fine mottled material are intercalated. In the distal parts intraformational mud clasts and rounded caliche pebbles are found. Sandstones consist of clastic limestone grains with minor amounts of quartz and alkalic feldspar grains.

The major part of the mud is mottled (see Fig. 5). In addition blue-grey mud is found. At the top of the northern part of the three-dimensional exposure a sudden transition of blue-grey to mottled mud is found (Fig. 3). However, the western longitudinal rise shows a profile with a gradual change of the colour of the sandstone. Normally grey-coloured sandstone passes upwards through the following range of colours; blue-blue with brown mottles-brown (sandstone with burrows)-brown with vertical blue mottles. The type of mottling agrees with the description by Buurman (1980) of Pseudogley type soils. Non-mottled mud of the three-dimensional exposure is found in laterally non-persistent layers (Fig. 5). Large amounts of plant debris are locally present. At the base of the interval mottling gradually disappears upwards $(\log 3$, Fig. 5). A thin lignite layer is intercalated in the blue-grey mud. In the basal parts of the mottled mud, thick caliche beds are found (logs 3 and 9, Fig. 5). The fine matrix may contain quantities of coarse-grained sand and some pebbles. 


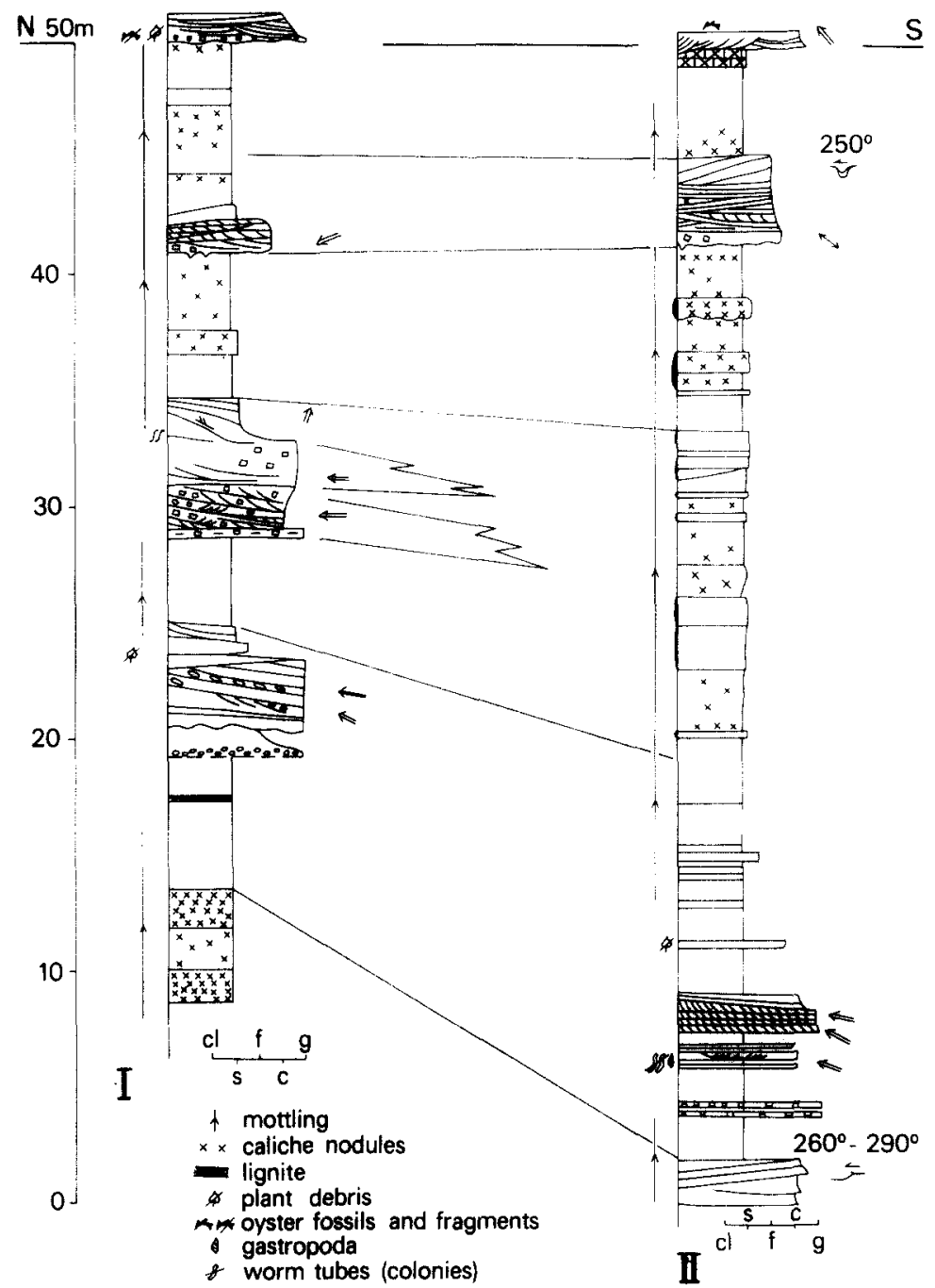

Fig. 2. Two general sections of the Monllobat Formation near Puente de Montañana (see Fig. ID for locations). The interval which has been studied in detail constitutes the basal parts. Note the thickening of mud sequences towards the south.

\section{Division of the exposures into lithofacies units}

Four lithofacies units have been distinguished on the basis of the geometry of the layers and the type of lithology (Figs. 3 and 4).

Unit I consists of two southwards dipping layers with nearly flat lower ends (Fig. 3). The lower layer makes up the major part of the northern transverse section. The upper and lower surface are undulating (Figs. 3 and 4). 


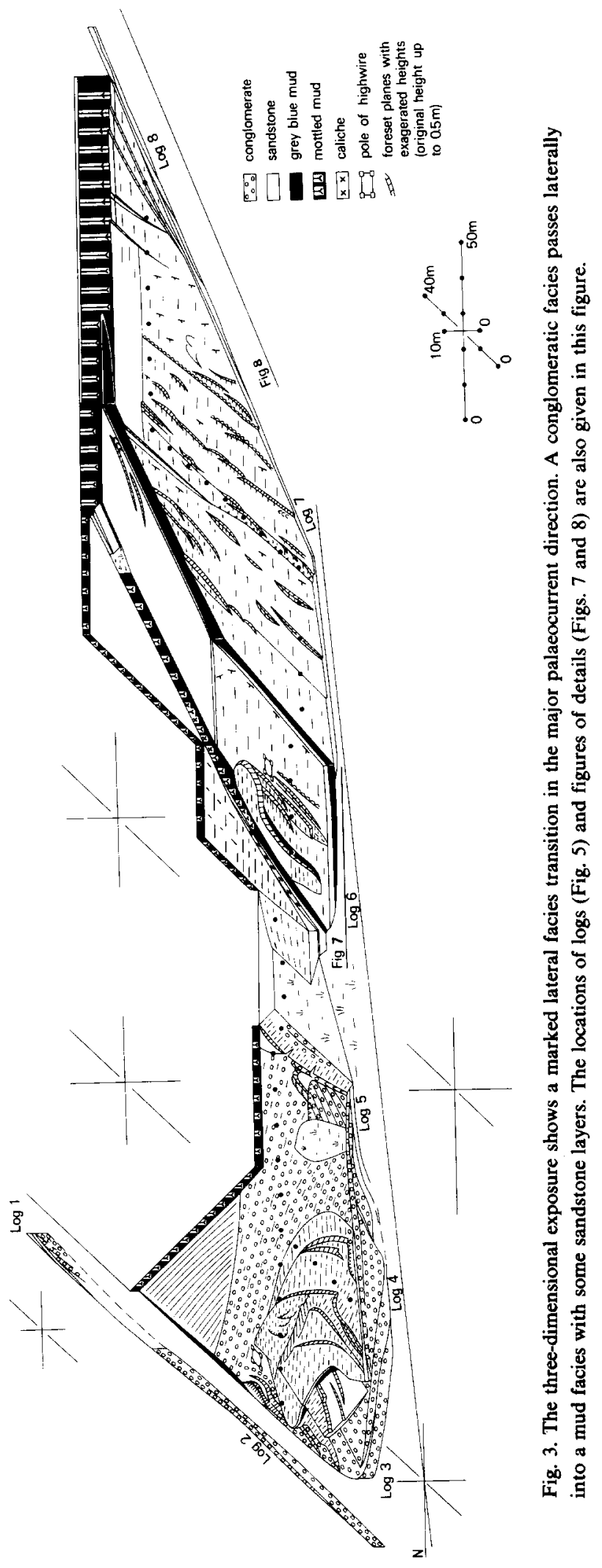




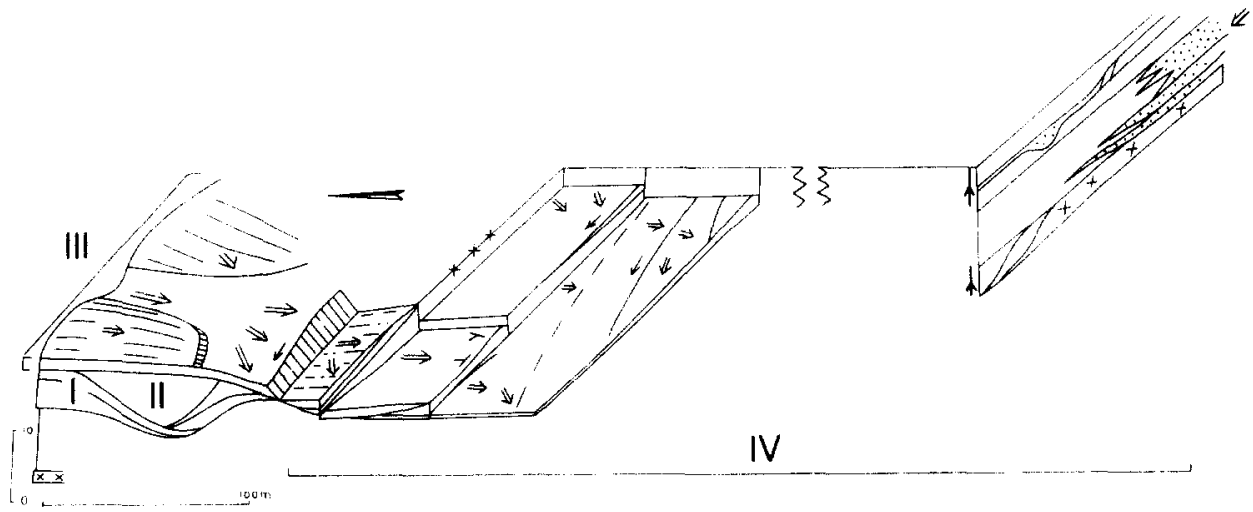

Fig. 4. A general view of the exposures in the investigated interval. To the north the exposure is three-dimensional (Fig. 3). To the south a vertical section is completely exposed (Fig. 10). The thickness has been exaggerated three times. Palaeocurrent directions are indicated on the top surfaces.

In the eastern thickening, large-scale foresetting is directed to the west (log 1, Fig. 5). The western thickening consists of massive conglomerate with some imbrication of flat pebbles $(\log 3$, Fig. 5) (directed to the southwest). The eastern part of the lobe is made up of conglomerate layers, some of which contain large amounts of rounded caliche pebbles ( $\log 2$, Fig. 5). Directions from imbrication and tabular cross-beds are to the west. In the longitudinal section massive and banded conglomerates of the two inclined $\left(10-15^{\circ}\right)$ layers pass downwards into flat sandstone beds with upcurved ends. These beds are massive (base of $\log 4$, Fig. 5) or tabular cross-bedded and cross-laminated (Fig. 6a) with northwestern palaeocurrent directions. Large tabular foresets (Fig. 6c) make up the slightly inclined $\left(5-10^{\circ}\right)$ top of the upper layer. The sandy conglomerates show some imbrication. The longest axis of elongated pebbles parallels the strike. Flat pebbles dip in an upstream direction when related to the foreset. However, the dip is downstream with respect to a horizontal face.

Unit II consists of southwards as well as northwards-dipping layers (Fig. 3). The bases of the southwards dipping layers are tangential to a northwards dipping truncation plane in the middle part of the unit. Northwards dipping layers underneath the truncation plane possess a flat upper part.

The southwards dipping layers show foreset structures in conglomerates and tabular cross-bedding in (conglomeratic) sandstone. Directions are to the southwest and the northwest, respectively. The beds underneath the truncation plane are coarsening and thickening upwards. Near to this plane parallel-laminated, inclined $\left(8-14^{\circ}\right)$ beds are topped by an erosive conglomerate bed. Distally tabular cross-bedded sandstone (southwestern direction) succeeds a mud-/sandstone interbedding (northwestern direction, $\log 5$, Fig. 5).

Unit $I I I$ consists of a flat layer with two north-south aligned thickenings. A steeply inclined $\left(20^{\circ}\right)$ face bounds the unit to the south (Fig. 6b). 


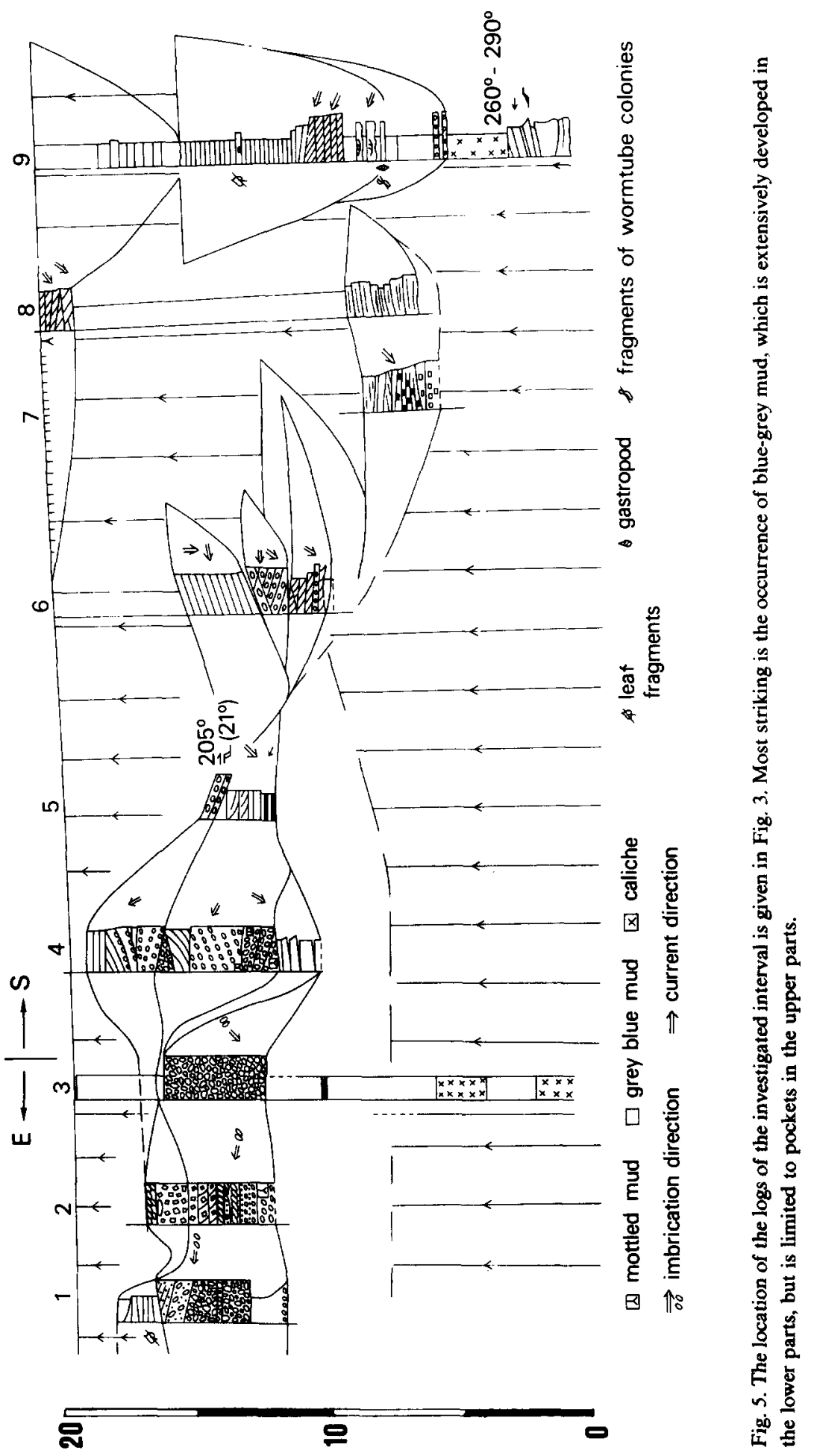


Most of the western rise is mottled. Mudstone is intercalated between the arcuate, inclined sandstone beds (Fig. 3). The top of the eastern rise is also mottled. Conglomeratic sandstone with tabular cross-beds makes up the core, which is covered by a convex sandstone layer. Massive conglomerates connect the two thickenings. To the south these conglomerates are tabular cross-bedded (top of $\log 5$, Fig. 5). The maximum $4.5 \mathrm{~m}$ high southern boundary face shows small slump scars at the top and a conspicuous fining upwards at the base from gravel to medium sand. Weathering of the southwestern part of the exposure has revealed stacking and overriding of tabular sets with arcuate foresets (Fig. 3). The large, inclined face is only a superficial feature.

Palaeocurrent directions of the largest features are to the south-southwest (see also Fig. 4). Close to the crest of the southern boundary face trough cross-beds in (conglomeratic) sandstone is directed to the west (see also Fig. 3). Deviating $340^{\circ}$ and $310^{\circ}$ directions are found on the lee of the western rise of unit I.

Unit $I V$ consists of several coarse layers embedded in fine sediment. Most layers wedge to the south. A deep-mud-filled depression separates this unit from units I, II and III.

The western longitudinal section of the three-dimensional exposure shows four subunits, of which only the upper three are well exposed (Fig. 7, location in Fig. 3).

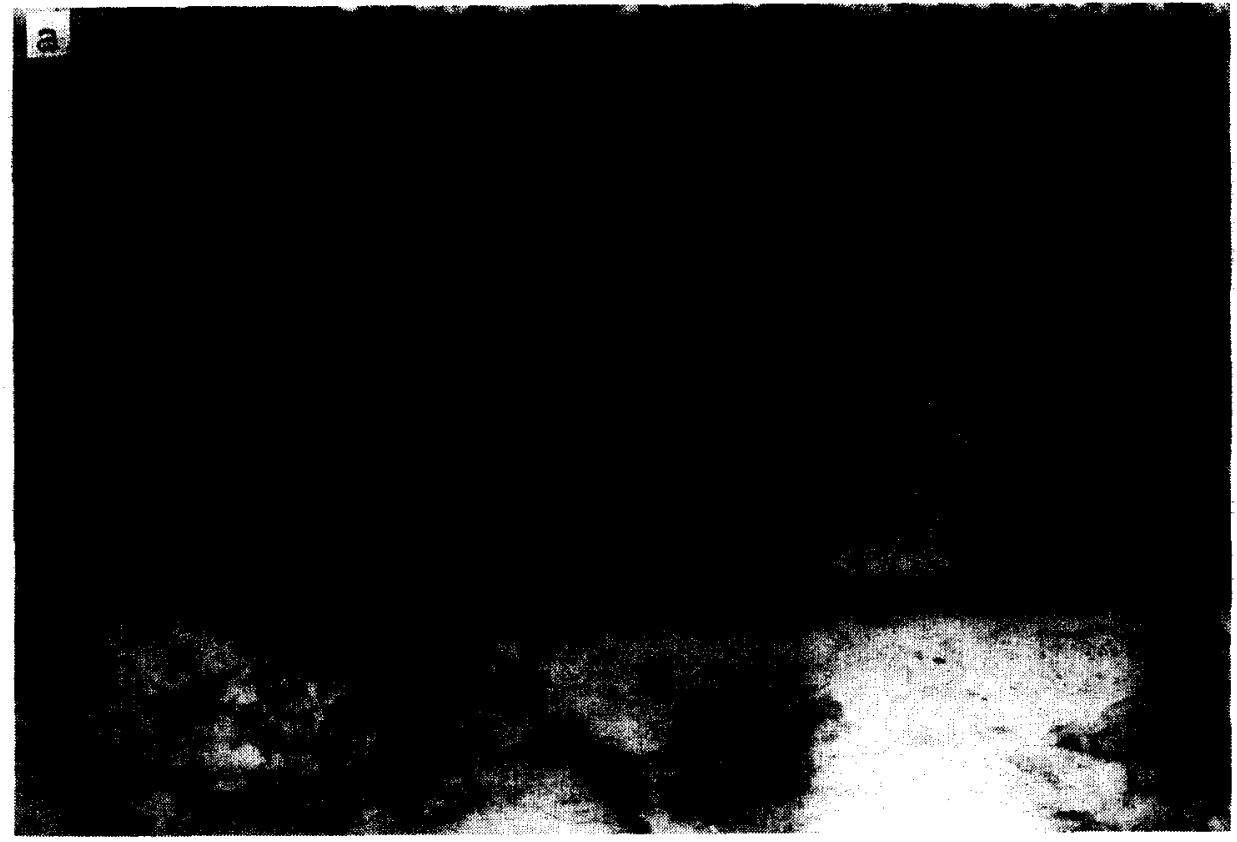



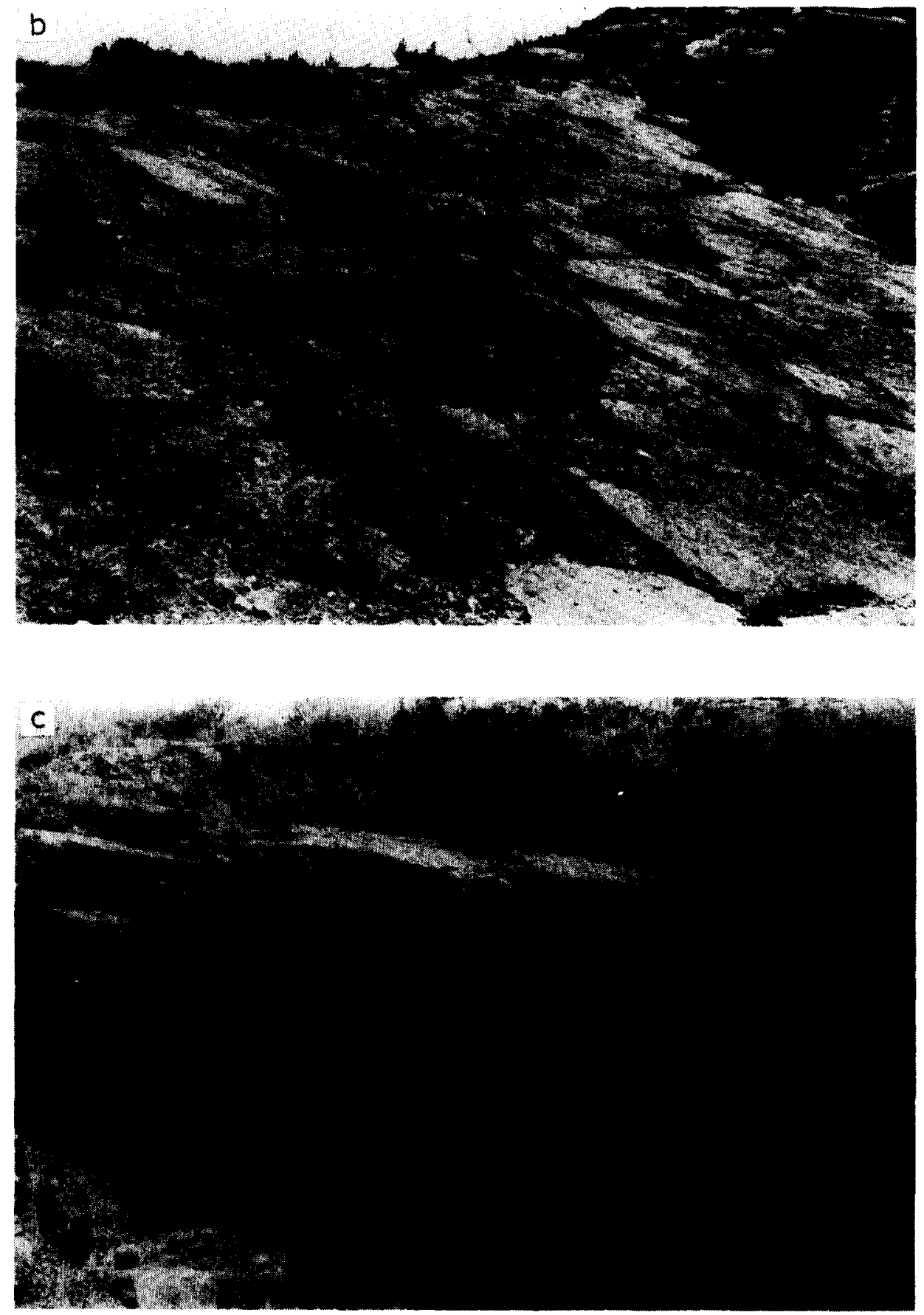

Fig. 6. a. Tabular cross-laminated sandbeds of the basal parts (bottomset) are incised by an (inclined) conglomeratic layer (foreset). A large, intraformational block (mottled, fine material) is intercalated. $b$. View of the maximally $4.5 \mathrm{~m}$ high foreset face, which bounds unit III to the south. c. Large cross-beds (scale is $0.5 \mathrm{~m}$ ) from the rather flat top of unit $\mathrm{I}$. 


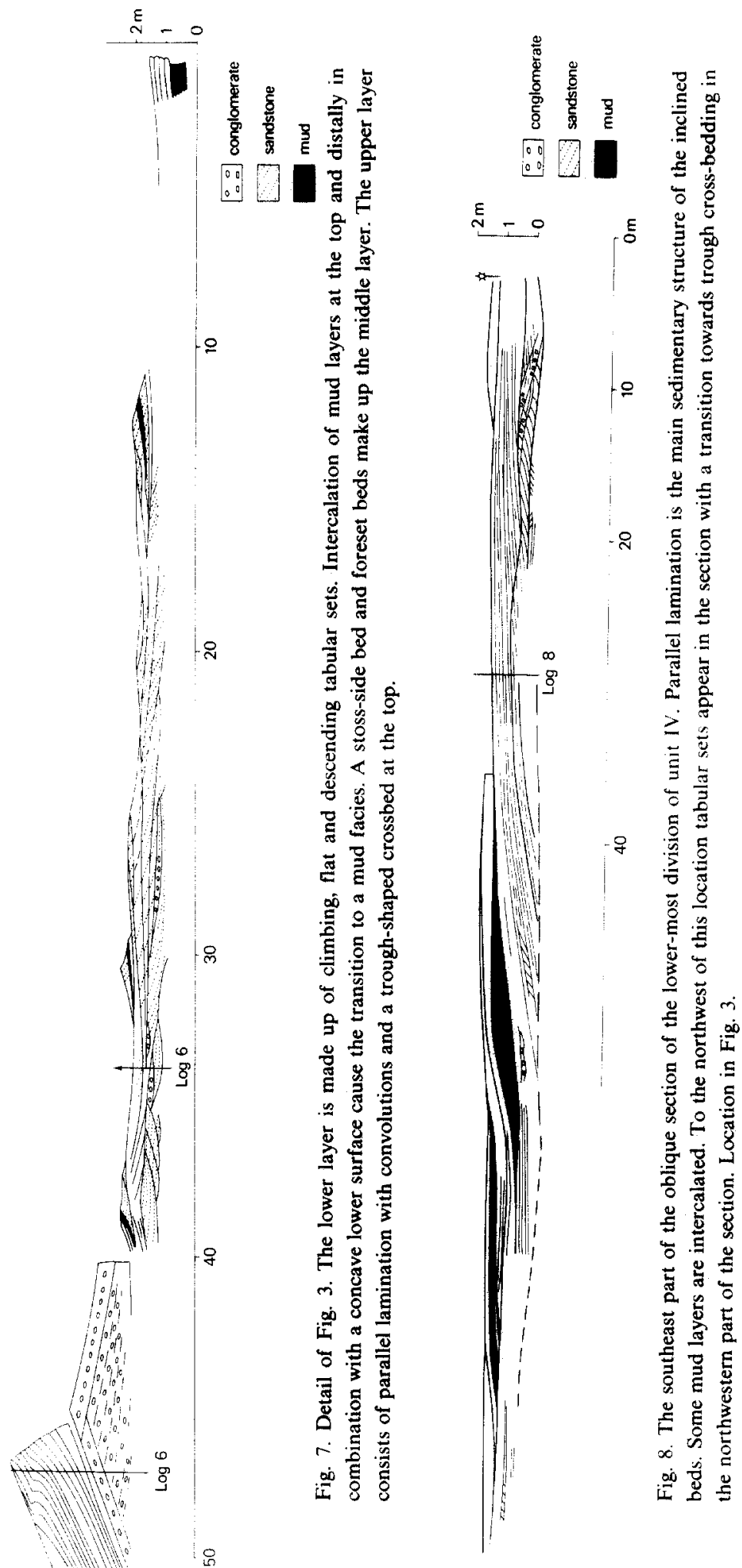


Massive, fine-grained beds of the lower exposed subunit succeed blue-grey mud (Fig. 7 and $\log 6$, Fig. 5). Laterally tabular cross-bedding is arranged in climbing, horizontal and descending sets. Climbing sets at the top of the section continue as climbing bedforms on the top surface. Directions are to the south-southwest.

The next subunit contains conglomerates, which contrasts with the composition of unit IV as a whole. Large foresets and a stoss-side bed are preserved. The subunit thins to the south and terminates in a curved foreset face with southern-southwestern directions. To the west side there is a pronounced northwestern deflection.

The upper subunit dips to the north, the top is flat. Parallel lamination is the main sedimentary structure with trough cross-bedding (Fig. 7) and tabular sets, both directed to the west. Convolute lamination appears at the top (Fig. 9a). The transition to a flat top part also goes together with thinning. This subunit again terminates in a curved foreset face (see Fig. 3).

The lowermost subunit of the three-dimensional exposure is well exposed in an oblique section (location in Fig. 3). Several inclined layers can be distinguished. From the southeast to the northwest the dip of the layers decreases. In the southeastern part parallel lamination drapes a convex upwards core (Fig. 8 and the base of $\log 8$, Fig. 5). The base and top of bent, inclined layers is flat. With decreasing dip, tabular and large trough cross-bedding is successively found.

The base of the subunit is made up of intraformational lags $(\log 7$, Fig. 8). The flat top part can be traced over the convex-upwards top surface (Fig. 3). A series of climbing, rather straight-crested bedforms (0.1-0.3 m thick) and inclined, parallel laminated beds $(0.1 \mathrm{~m}$ thick) form reliefs up to $0.5 \mathrm{~m}$ high. Erosive trough-shaped sets (0.02-0.1 m thick) are directed at right angles to the straight-crested bedforms.

Two trends accompany the westwards lowering of the top surface.

(1) In the eastern parts layers are erosive to each other; to the west well-developed coarsening-upwards sequences are found and mud is intercalated between the layers. The eastern deposits are relatively coarser.

(2) Crescent-shaped bedforms are linguoid to the east and barchanoid to the west (Fig. 3). Palaeocurrent directions are to the south, but at the western margin strong northwestern deflection is found. Linguoid forms possess low-angled, lobate foresets (dip $8-10^{\circ}$ ). The stoss side dip $10-14^{\circ}$. The foreset dips of barchanoid forms have a very wide range $\left(13-30^{\circ}\right)$. Stoss-side dips vary from $8-15^{\circ}$. The two bedform types are represented in Fig. 9b,c.

The succeeding subunit at the western side also shows the second trend on a convex-upwards top surface. The basal surface is concave upwards in the southern as well as in the eastern direction and wedges rapidly. To the east a flat layer has the same southwards extension.

The upper two subunits at the western margin dip to the north. However, the rather flat upper ends are convex upwards in a W-E direction (Fig. 3). In this direction the upper subunit wedges against the lower. Further to the east the lower one passes over into a thin caliche layer at the centre of the exposure. On the same 
level 0.2 and $0.5 \mathrm{~m}$ high foreset faces are found on the eastern side (Fig. 3). The foresets are made up of mottled silt.

A thin subunit at the southeastern top of the three-dimensional exposure can be traced into the tributary valley to the south of Puente de Montanana (Figs. 3 and
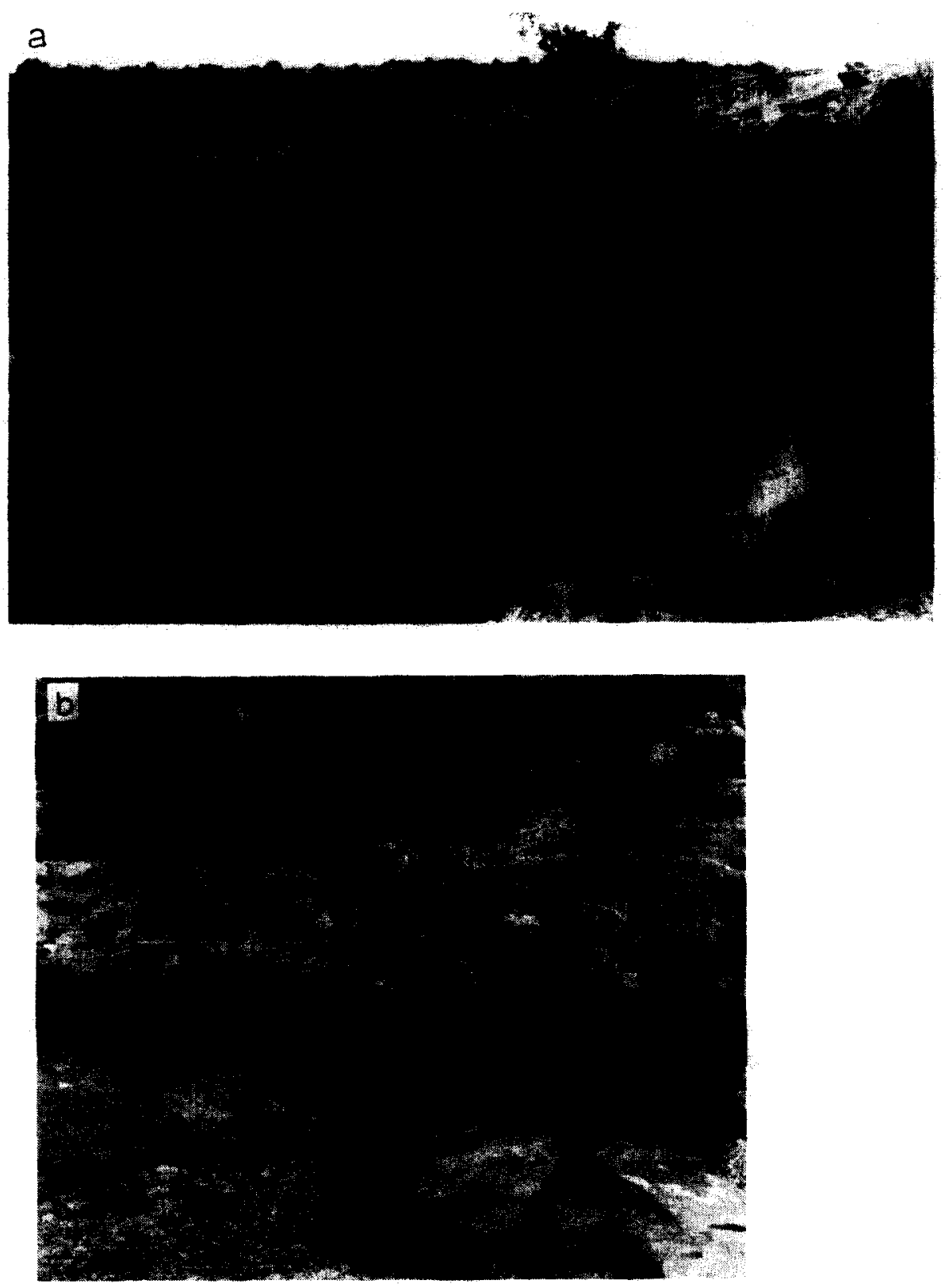

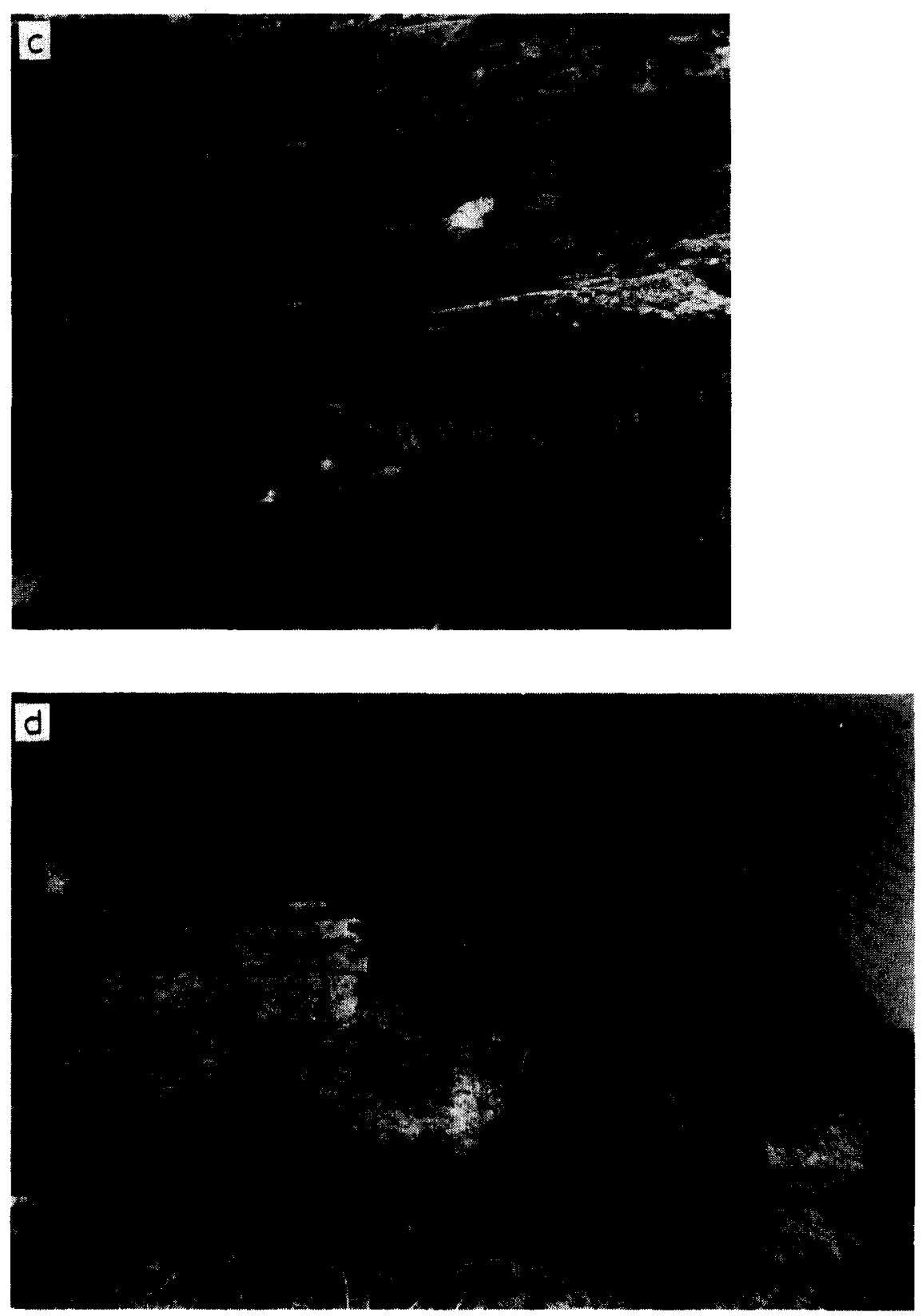

Fig. 9. a. Convoluted parallel lamination from the northwestern part of unit IV (upper layer in Fig. 7). b. The rather low-angled foresetting constitutes a lobate set with slightly erosive base (part of a lingoid bedform, southeastern top of the lowermost division, Fig. 3). c. High-angled foresetting of a barchanoid bedform (southwestern top surface of the lowermost division of unit IV, Fig. 3). d. A transition of trough-shaped to tabular sets of cross-bedding in the lowermost subunit of the southern vertical section (Fig. 10). 


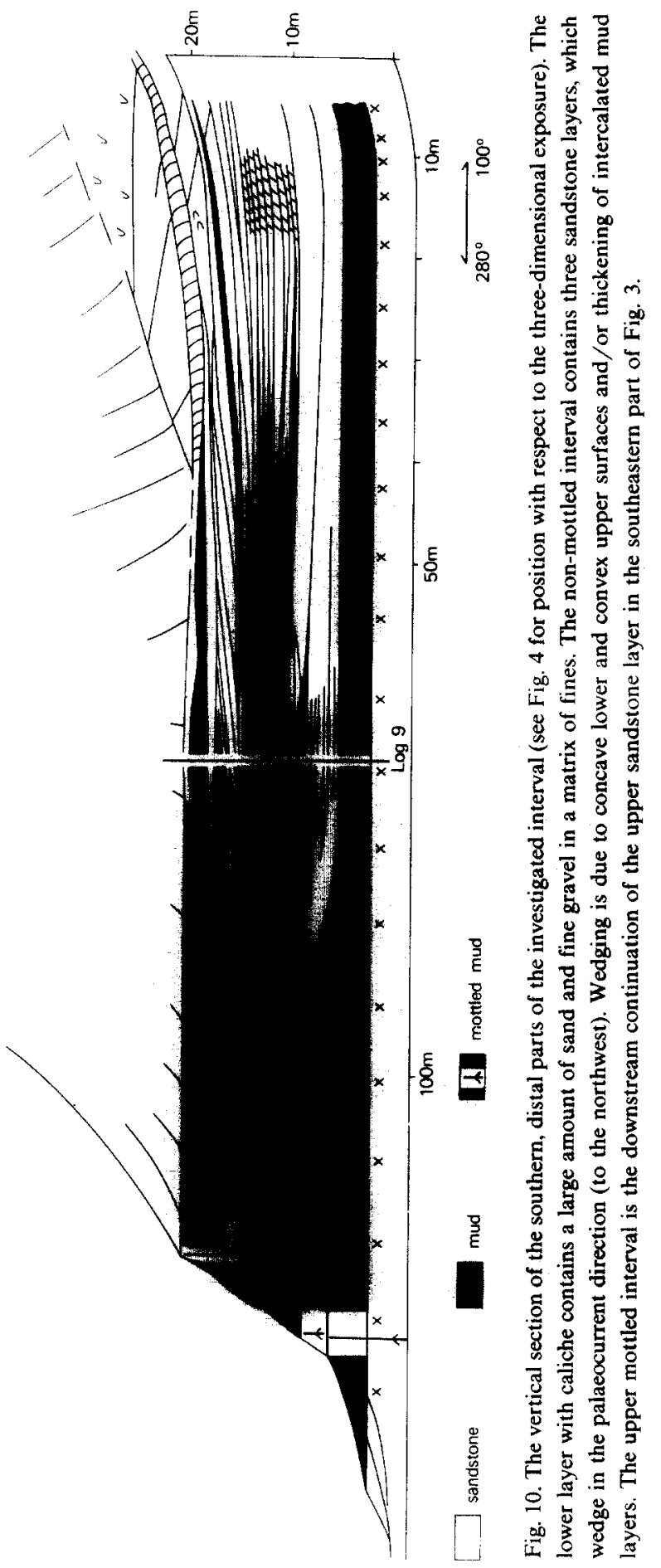


1D). The subunit thickens in this direction. Tabular cross-bedded sandstone $(\log 8$, Fig. 5) passes into a completely mottled silt/mudstone interbedded with minor sandstone intercalations $(\log 9$, Fig. 5). In the tributary valley, flat sandstone layers also are embedded in mudstone. The down-current extension of three non-mottled subunits (Fig. 10) decreases successively upwards, as was the case in the three-dimensional exposure. However, the palaeocurrent directions are to the northwest, instead of to the south. Tabular cross-bedding is the main sedimentary structure. The lower subunit shows a lateral transition of large trough-shaped sets to tabular cross-bedding (Fig. 9d). At the base there is an intraformational lag interbedded with parallel-laminated, fine sediment. This material shows an alternation of very fine sand and mud laminae with leaf imprints. Fossils (amongst them oysters) are also found in the base of the non-mottled interval on the opposite valley wall.

The described section (Fig. 10) is parallel to the northwestern palaeocurrent direction. Therefore the details of a transition to a complete mudstone sequence can easily be distinguished. A combination of convex-up or flat top surfaces and concave-up basal surfaces causes the wedging of sandstone layers in a grey-blue mudstone sequence. This transition can also be the direct result of increasing thickness of intercalated mud layers together with thinning of cross-bedded sets.

In the mottled top part, the thickening of intercalated mud layers also plays a role in the southwards thickening of the continuous subunit at the top of the interval. Intercalated sandstone layers terminate in a foreset plane (Fig. 10). Only a coarsegrained sandstone lens with flat siltstone wings can be traced further to the south. Siltstone layers contain nodular caliche.

\section{Sequences}

The described characteristics lead to coarsening-upwards sequences in the mainly conglomeratic, proximal parts (unit I, II and III). The decreasing extent of sandstone layers up to the top of unit IV formed a majority of the fining-upwards sequences. Proximal as well as distal sequences are topped by a thin fining-upwards layer. The distal top lies somewhat higher than the proximal top.

The presence of large-scale erosion planes in unit I and II involves occasional truncation of the basal sandstone parts. Inclined layers of unit I and II are mostly bounded by erosion planes. However, part of the lower layer of unit I shows a flat top draped by mud. The mud layer is overlain by mud pebbles and conglomerates on an erosion plane. Intercalation of mud layers is also found in the lowermost division of unit IV in the three-dimensional exposure.

\section{ENVIRONMENTAL RECONSTRUCTION}

Several features indicate that the deposits were formed in a fan-delta environment. 
(1) The marine fossils in the distal base of the interval point to the presence of marine standing water. Large quantities of fine material are mottled under subaerial conditions.

(2) The morphology of the layers and the direction of the largest sedimentary structures originated during a progradation process towards the marine environment.

(3) The environmental setting on a large-scale involves sediment supply by a small alluvial system transporting immature clastics from the rising Pyrenees (reconstruction in Van der Meulen, 1982). Lithofacies unit III represents the deposits and abandonment relief of a shallow, braided stream.

Wescott and Ethridge (1980) distinguish three subenvironments of the fan-delta; the fan-delta plain, transition zone and submarine fan-delta. The described deposits are the results of sedimentation processes in the transition zone of a fan-delta.

\section{Evolution of the sedimentary relief}

Three major phases can be distinguished, corresponding to the sedimentary relief (Fig. 11).

Phase 1: Sediments were deposited on a southwards dipping fan-delta face, which was undular in a transverse direction. The coarsest sediments are found where deposits are thickest. Gravel grades to sand downwards over the face. At the base there was a west-northwest deflection of currents. Mud was deposited at some distance from the fan-delta face.

Phase 2: The rise in front of the face was draped by sand beds deposited from southwest directed currents. These deposits have been partly eroded during continuing progradation.

Phase 3: Deposition was mainly to the south of the previously formed sediments of unit I and II. The relatively thin unit III on top of units I and II was formed simultaneously. This is indicated by the similar palaeocurrent directions from the southern boundary face of unit III and the transverse bar buildups of unit IV adjacent to the face. The unit IV lithofacies is largely different from unit II facies at the same level underneath the inclined face (compare Fig. 7 and $\log 5$ of Fig. 5).

The development of unit IV can be divided into three subphases, however, the sedimentary processes leading to unit III cannot be unraveled. Deposits of unit III consist of convex-up, longitudinal bars, two of which are now exposed. The western rise of unit $I$ formed the nucleus for the accretion of sand and mud beds. In the course of phase 3 , the stream bed aggraded and longitudinal bars became more closely spaced.

In front of unit III, sediments were deposited by sheet flow over the southern area of the three-dimensional exposure during phase $3 \mathrm{a}$. During phase $3 \mathrm{~b}$ two sandstone layers were formed, separated by a small mud area. With the progradation of the central gravel bar in the upstream parts, the mud zone developed into a mud rise on 

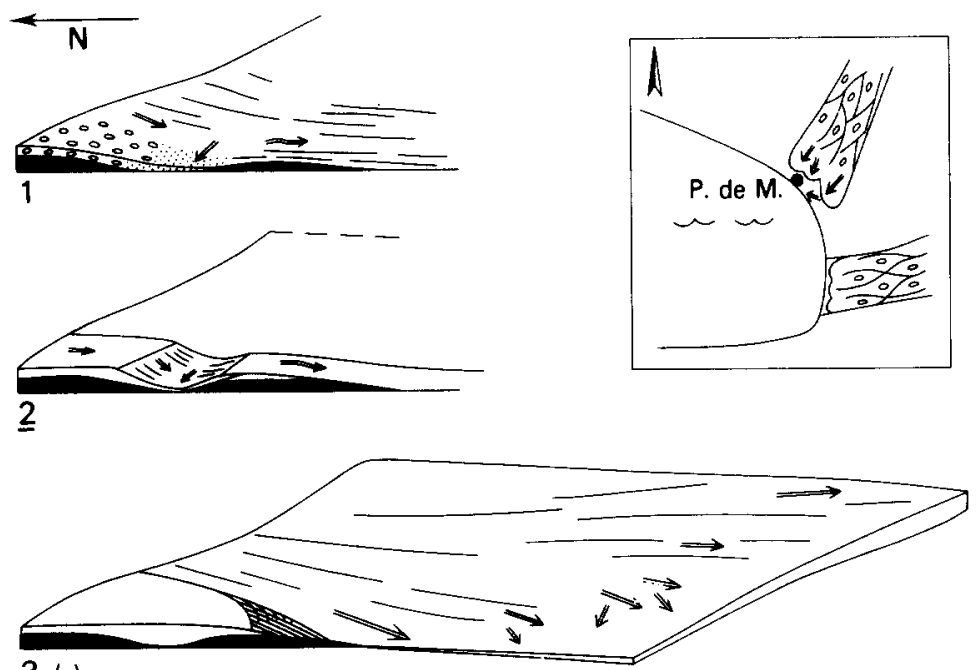

3 (a)

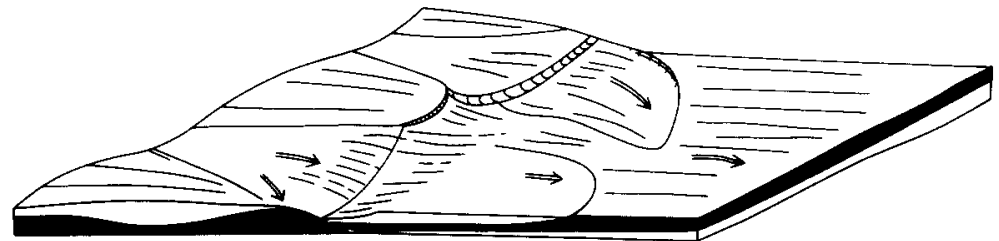

3 (b)

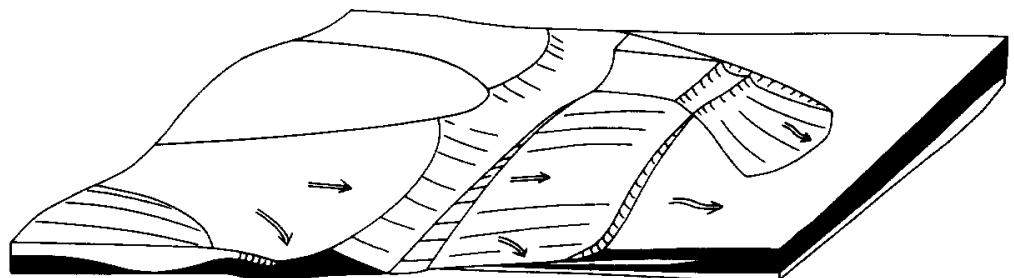

3 (c)

Fig. 11. A reconstruction of the evolution of the sedimentary relief during three successive sedimentation phases.

the leeside of the longitudinal bar. During phase $3 \mathrm{c}$ a channel was scoured on the eastern side and erosively based, coarse layers draped the western side.

Concurrently strongly deflected currents deposited sand layers further to the south. This situation is sketched in the inset of Fig. 11.

Finally a flat sandstone layer, that grades to mud in the palaeocurrent direction, was deposited by sheet flow over most of the transitional fan-delta deposits. 


\section{Reconstruction of discharge conditions}

Sedimentation of the gravel layers of units I and II was preceded by erosion. Occasionally a noneroded, flat surface, covered by a mud layer was preserved. Mud pebbles in the succeeding conglomerates indicate erosion after a period of time sufficient for mud compaction.

McGowen (1970) demonstrated that alluvial sediment supply to a recent fan-delta was restricted to storm periods with large amounts of precipitation. It is likely that the layers of unit I and II, bounded by large erosion planes, were also formed during rather short sedimentation events. Flow energy must have been very high. During waning flow conditions, mud was deposited.

The intercalation of mud layers in the lowermost division of unit IV points to a development due to a succession of several sedimentation events. The upper divisions of this unit do not show intercalated mud layers and will have been formed during one event. The limited extent of the subunits agrees with such a conclusion. As stated before, unit III does not show an alternation of facies successions on a large scale. However, a small-scale alternation of sand and mud beds is found in the western rise of the unit.

\section{INTERPRETATION OF HYDRODYNAMIC CONDITIONS AND SEDIMENT MOVEMENT}

\section{Interpretation of rivermouth processes}

Sandstone layers in front of the fan-delta face are of limited lateral extent (Fig. 11). The sedimentary relief of the shallow, braided river evidently was high enough to cause jet flow. In the proximal parts, the coarsest sediments are found where deposits are thickest, due to concave-up basal surfaces and convex-up top surfaces. This lateral variation points also to a certain degree of confinement of the main outflow.

Sediments reworked by marine agents as described by Wescott and Etheridge (1980) from the transition zones of fan-deltas have not been found. The major part of the distal sequence of the three-dimensional exposure consists of mottled mud. The pseudo-gley type of soil formation developed under mainly subaerial conditions. The geometry and sedimentary structures are considered to be solely the result of outflow processes at the mouth of an alluvial stream.

Farquharson (1982) described flat mouth bar-type deltas and a Gilbert-type delta (well-developed foresets), intercalated in a Mesozoic alluvial sequence. The deltas were formed in shallow lakes, which involves rather thin units (up to $14 \mathrm{~m}$ thick). The thickness of deposits described in this paper also falls within this range. Further there was also a lack of reworking processes.

Farquharson (1982) made the interpretation that the two delta types originated during hyperpycnal and homopycnal inflow, respectively. 
Hyperpycnal inflow (more dense than receiving basin waters Bates, 1953); formed a plane jet underneath the basin water. Bottom friction caused deceleration and consequent mouth bar sedimentation (Wright, 1977).

Homopycnal inflow (as dense as receiving basin) formed a turbulent, axial jet. Flow deceleration and consequent sedimentation was due to inertial forces.

Hypopycnal inflow (less dense than receiving basin) did not play a role in the freshwater basin; this type of inflow forms a plane jet on top of (salt) basin waters. Expansion decelerates the flow from which suspended sediment settles. In our case, the large amounts of gravel in the proximal parts and the geometry and structures of the distal parts rule out this possibility.

The delta type which was described changes from a Gilbert- to a mouth bar-type in the progradation direction. Farquharson (1982) suggests that the single Gilberttype delta might be formed during a period with decreased suspension load. A similar variation of the sediment type did not occur during fan-delta progradation, as is pointed out by the large mud contents of lithofacies unit IV. The decreasing slope does accompany a disappearance of gravel from the sequence.

It can be concluded that, although fan-delta deposits originated during jetflow, inflow models from the deltaic environment cannot be directly applied.

\section{Analysis of the three-dimensionally exposed units III and IV}

A starting point for the reconstruction of hydrodynamics and sediment transport is found in the three-dimensionally exposed units III and IV (phase 3, Fig. 11).

(1) Unit III records a period of progradation of a braided stream in the area. Aggradation of the stream bed accompanied progradation. Gravel was unable to pass over the top of the western rise. Curved, low-angled sand and mud beds accreted on the lee. Transverse bars with flat tops developed during continued enlargement. The eastern rise was mainly built by transverse gravel bars with high-angled slip faces. However, most of the gravel passed through the central depression. The continuous sand covers point to sediment settling all over the rises, prior to abandonment.

Superficially erosive features indicate flow over the top of the rises into the depression. Channelized flow in the depression also caused some erosion of the rises and directed a small gravel bar up against the western rise (see also Fig. 3). The maximum depth of the channel relative to the top of the rises is $2 \mathrm{~m}$.

The western orifice for jetflow was formed by the downstream terminations of the rises (Fig. 11, phase 3b, c). Gravel sedimentation and consequent shallowing accompanied flow expansion. With increasing flow expansion, transverse gravel bars with linguoid shapes were formed. Stacking and overriding of successive gravel bars during the whole of phase 3 has caused the transition of a low-angled to a high-angled fan-delta (foreset) face.

(2) Unit IV: the most extensive division of this unit appears at the base (phase 
3a). Marine fossils further distally point to marine conditions nearby. The top of this subunit and the mud sequence on top are mottled. This sequence involves a transition from inflow in a standing body of water to inflow strongly obstructed by a mottled mud rise. Therefore it is concluded that frictional forces must have played a role of increasing importance during phase 3.

The erosive base and intraformational lags of the lowermost subunit are indicative of strong friction, even during phase 3a. During phase $3 \mathrm{~b}$ coarse deposits, enveloped by grey-blue mud, filled scour hollows. During phase $3 \mathrm{c}$ deposits with erosive bases were draped against and over the mottled mud rise in front of the fan-delta face.

The geometry of the lowermost subunit developed in standing water. However, the lobate shape pointing upstream differs from the lunate shape of a mouth bar, formed due to frictional resistance to hyperpycnal inflow (Bates, 1953; Wright and Coleman, 1974). Lunate mouth bars consist of a transverse bar linked with subaqueous levees. The sedimentary structures are also much larger than those described by Farquharson (1982) from mouth bars.

The geometry of the subunit does resemble the build-up of a sieve lobe as described by Rachocki (1981, fig. 34) from a small scale alluvial fan. The lobe developed in the proximal area where sheet floods suffered extreme losses of transport capacity due to infiltration. The extent of the surface layers upwards decreases as in our example. Also the extension on the margins is further than on the top, where also some erosion occurred. The downstream end of the layers represents the "frozen" front of successive sheetfloods (Rachocki, 1981). The composition of the sieve lobe and the subunit are not the same. Gravel and sand are found respectively. However, large-scale climbing bedforms indicate also very rapid loss of transport capacity.

The climbing bedforms on the surface are crescentic. McBride (1962) ascribed a transition of continuous straight-crested to isolated crescentic bedforms in the cross-laminated division of a turbidite to sedimentation during waning flow. Relatively small trough-shaped sets, directed at right angles to the climbing bedform relief, have been described from the three-dimensional exposure. It is likely that climbing bedforms developed first during waning flow. Subsequently low-velocity flow became deflected and confined by the sedimentary relief, building up erosively based trough-shaped sets. The transition of linguoid bedforms on the convex-up top to barchanoid forms at the low margin is a consequence of erosion of the crest of the former structure. Erosion did not occur at the lower margin. Internal structures show a deviating trend. The transition from parallel lamination to tabular cross-beds was promoted by increasing depth towards the margin. However, flow became confined at the margin during the earliest stages and large trough crossbeds were formed. Distally the trough cross-bedding may have passed into tabular cross-bedding of a smaller size; a transition, which was observed in the lateral equivalent to the south (Fig. 9d). 
It can be concluded that there are several indications of rapid sedimentation. The geometry and the large-scale bedforms on top of the lowermost subunit point to rapid sedimentation from sediment-laden currents. The transverse bar build-ups and convex layers close to the foreset face also involve rapid sedimentation. The degree of turbulence of the inflow cannot be reconstructed on the basis of the exposures, but it is likely that inertial forces also played a role during the sedimentation process, by creating strong turbulence, keeping large amounts of sediment in suspension.

\section{Application of a model of recent highly energetic inflow}

An example of modern highly energetic inflow with resembling relief is found where a hydro-electric station debouches in the Rio Ribagorzana (some $4 \mathrm{~km}$ to the south of Puente de Montañana). Shooting flow enters an abandoned reach under a high angle (Fig. 12). Inertial forces cause high turbulence and consequent deceleration in a pit in front of the orifice. Slowed-down flow is deflected towards a shallow channel and enters the main stream. However, part of the inflowing waters is directed back to the orifice forming a return current around a large-scale eddy (Fig. 12). The water-air surface is depressed on the location of the eddy, with an adjacent rise of highly turbulent waters. The surface of the inflow lies higher than the Rio Ribagorzana level. Waters in front of the orifice consist completely of previously discharged waters, because of constant mixing and refreshing.

The model represents very well the deflection of flow due to the perpendicular to oblique entry of the marine basin by the alluvial streams (inset of Fig. 11). It is also clear that high-velocity flow entering a shallow environment from a shallow river

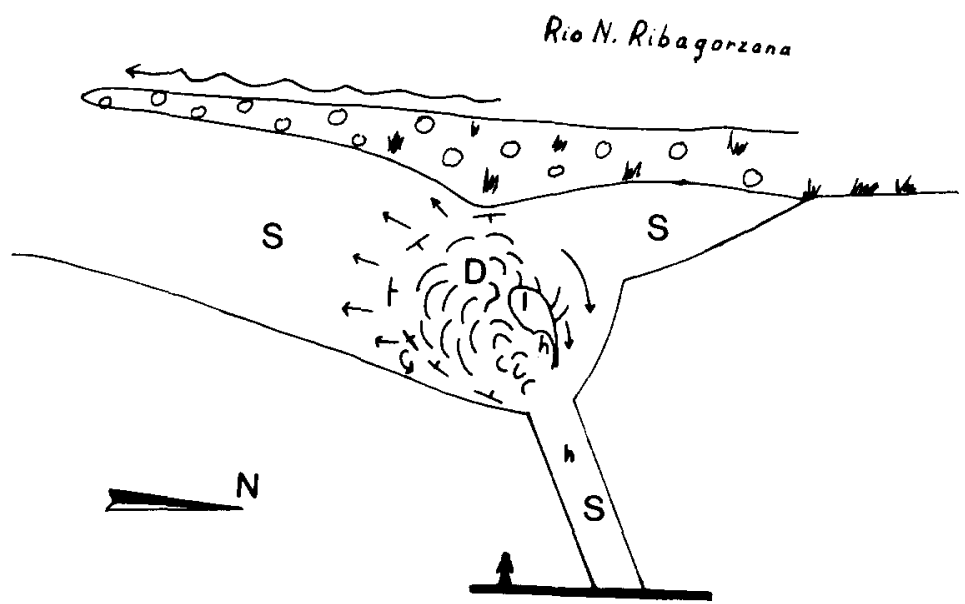

Fig. 12. Inflow in an abandoned reach of the Ribagorzana River from a hydro-electric station. Shallow $(S)$ and deep $(D)$ parts of the sedimentary relief are distinguished. Further relatively high $(h)$ and low $(l)$ positions of the level of the inflow are indicated. 
must have brought about large-scale turbulence due to inertial forces. Therefore the preceding analysis of three-dimensionally exposed units III and IV can be expanded.

Phase 1: Gravel sedimentation on the steeply inclined foreset (unit III) face was due to avalanching of overriding, transverse bars (phase 3). Expansion at the orifice caused sufficient flow deceleration to prevent gravel transport over a moderately inclined foreset. During phase 1 such transport was possible. Inertial forces decelerated the flow over the foreset face, causing a fining downwards to sand. Concaveupwards sand beds may point to some erosion at the base and consequently to the operation of frictional forces. The large-scale turbulence caused by inertial forces close to the orifice broke down at some distance from the foreset face with consequent dumping of the suspension load.

Phase 2: During further progradation parallel-laminated sand beds draped the initial suspension-load deposits and a rise developed (Fig. 13). On the flat top of the rise, seawards-directed tabular cross-bedding was formed. The same type of deposit forms the northwestern top of unit IV.

Landwards dipping, low-angled lamination in combination with flat-bedded sand may represent berm-flat backshore zones and the backshore zone, respectively (Wescott and Ethridge, 1980). However, palaeocurrent directions from the flat

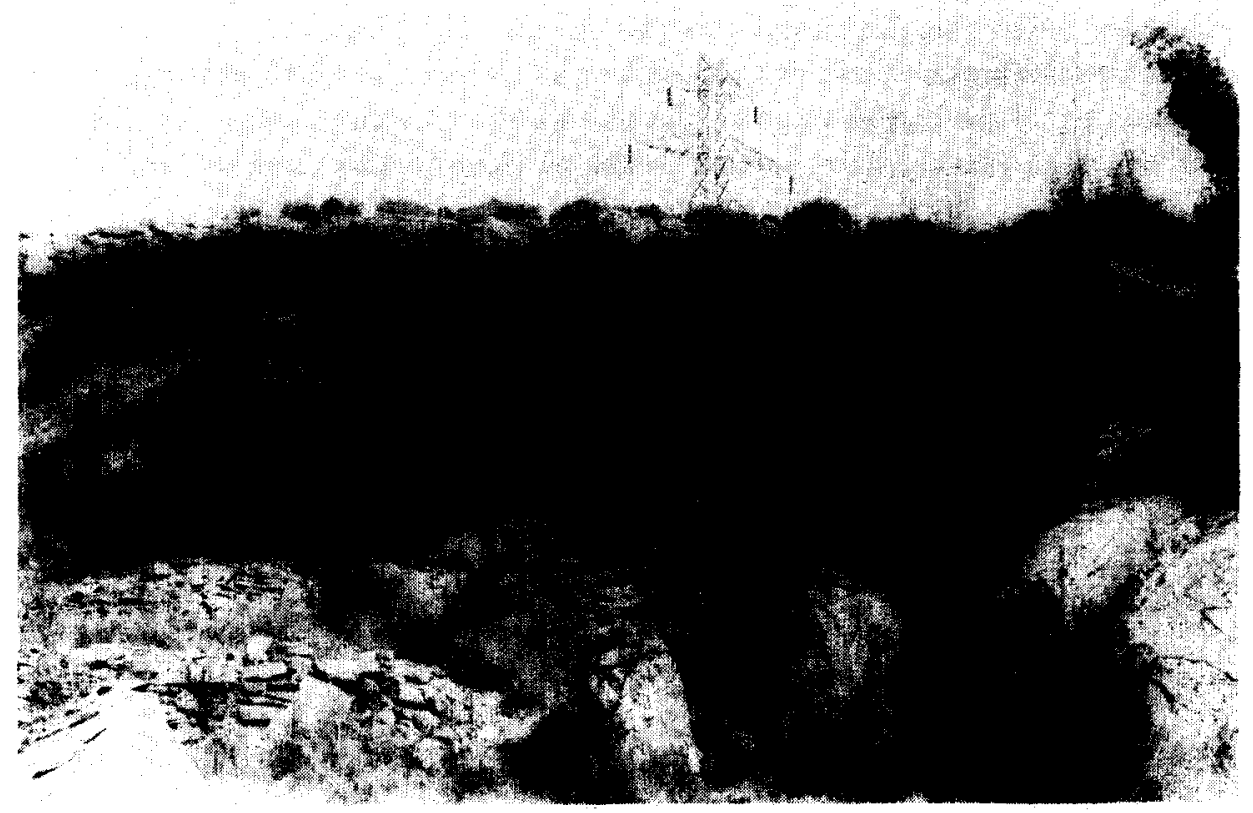

Fig. 13. The distal parts of units II and III. To the right (south) $\log 5$, Fig. 5 is situated. Northwards dipping, parallel-laminated layers possess flat upper ends with tabular cross-bedding (unit II). Unit III truncates unit IV 
tabular sets indicate seawards transport. Further unit IV deposits of this type are embedded in mottled mud and there is no connection with the marine environment.

The deposits inclined against the main palaeocurrent direction resemble backsets. Davis (1890) described backsets in combination with downstream foresets situated in front of a receding glacier. Jopling and Richardson (1966) produced backsets in a hydraulic jump in a shooting flow. Addition of upstream backsets and downstream foresets could be achieved by raising the baselevel. In the case of unit IV raising of the baselevel was accompanied by heightening of the orifice at unit III. Therefore backset sedimentation was due to flow deceleration caused by friction at the sediment rise in combination with mainly vertical expansion in front of the orifice. Unit II backsets coarsen upwards and the top is truncated due to continued progradation.

Phase 3: The indications of rapid sedimentation from unit IV, such as large-scale climbing bedforms, can be better explained when the effects of inertial forces are considered. Large amounts of suspended material became available for sedimentation in the zone where large-scale turbulence broke down in scour pits. The coarser fractions were stored in transverse bars. A more gradual decline of turbulence will have taken place during phase $3 \mathrm{a}$ when there was a connection with a marine environment.

A highly turbulent flow keeping large amounts of sediment in suspension may easily pass into a turbidity current, provided that the submarine slope is steep enough. Then an originally fluid gravity flow can pass over into a self-propelled sediment gravity flow (Middleton and Hampton, 1976). The flow was then driven by gravity acting on the sediment instead of on the flow as a whole.

Laminated intercalations of very fine-grained, detrital limestone in between intraformational lags in the deepest, distal parts (phase 3a) may represent respectively the deposits of the tail and the traction carpet of a differentiated turbulent flow. Sneh (1979) describes large amounts of laminated, detrital limestone from the distal parts of a fan-delta.

The relevance of the model for highly energetic inflow is pointed out by another exposure from the northwestern parts of the Monllobat Formation. Mottled sandand siltstone layers make up layers with a large-scale curvature adjacent to a conglomeratic rise. On the lee of this rise cross-bedding is directed towards the rise. In a minor way such a facies was also present in the northwestern thickening of unit III. The arcuate ridges of cross-bedding (Fig. 14) are lying against low gravel ridges. The ridges are the continuations of the inclined beds on the gravel platform.

The conglomeratic layer can be traced over several kilometers in a transverse direction. To the east the next conglomeratic rise is situated at a distance of a few hundreds of meters. Downcurrent there is a complete transition to graded sandstone beds and mottled fine material. The southern log shows a regressive, fining-upwards sequence. Blue-grey sandstone beds are found at the base. Large foresets with a flat 


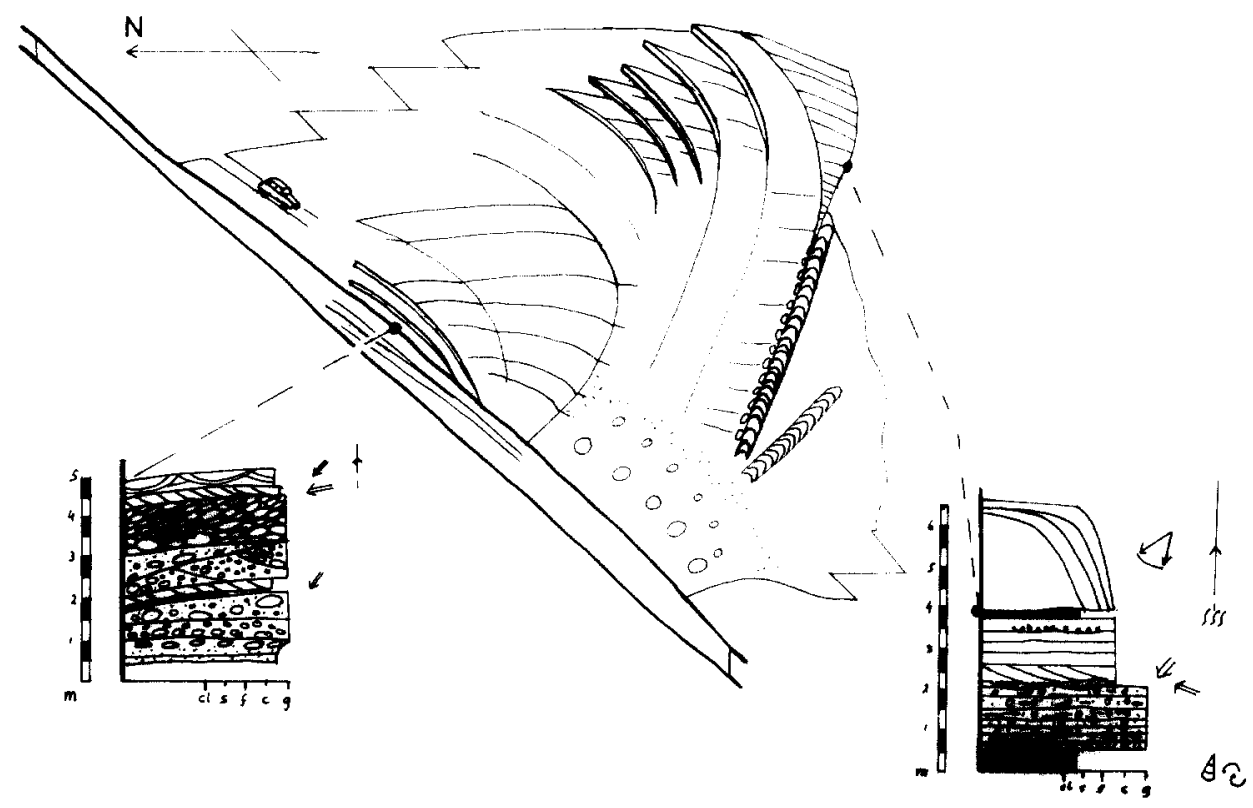

Fig. 14. A conglomeratic sheet passes downstream (to the south-southwest) over in sand-and mudstone. Alongside a massive conglomerate thickening arcuate, inclined layers are found. The continuations of these layers on the lee of the conglomeratic thickening show cross-bedding, developed by return flow.

top grade upwards from sand to silt. The completely mottled terminal foresets on the location of the $\log$ are covered by mottled mud. The proximal $\log$ shows a highly differentiated conglomeratic facies. The convex-upwards layers pass laterally over into massive conglomerates of the western rise.

\section{SEQUENCES}

Rapid aggradation exceeding initial water depth took place because of the supply of large amounts of sediment. The differences between proximal and distal sequences were the consequence of a decrease of flow energy and pronounced fining of the sediments in the last stages of fan-delta progradation, when gradients were lowest and finest sediment was supplied. The response of the sedimentary environment has been described in detail above.

\section{THE SETTING OF FAN-DELTA DEPOSITS IN STRATIGRAPHIC SECTIONS}

Both at the base and the top of sections I and II there are indications (oyster fossils) of the proximity of marine deposits. The stratigraphic interval as a whole represents a period of increased activity of alluvial streams in the area. However, within the interval a gradual decreasing activity can be observed, with extensive 
caliche formation and a transgression at the top. Such a succession agrees with the model for sedimentary cycles of the Monllobat Formation (Nijman, 1981). Maximal progradation of the alluvial systems will be due to maximal gradients during the transgressive phase.

Point-bar deposits close to the top of section II form a deviation of this sequence. A fan lobe passes downstream over into meandering river deposits as occasionally can be observed within the Monllobat Formation (Van der Meulen, 1982). There are two indications that caliche formation was related to alluvial sedimentation and that there was no distinct link with the occurrence of transgressions, as suggested by Nijman (1981).

(1) Caliche layers are regularly distributed over section II. Similar alternations are found in the distal parts of the upper division of unit IV (Fig. 10) and of the fan lobe succeeding the three-dimensional exposure. The caliche formation may very well have been the result of the evaporation of ground-water discharge through the alluvial deposits. McGee (1897) described migration of rainwater through deposits after rates of precipitation insufficient to cause run off through the channel.

(2) A prominent caliche layer has been developed prior to a transgressive phase-especially at the base of the sections I and II. Instead of being developed during a period of minor sedimentation (Nijman, 1981) this layer may represent the first indication of a steepening of relief due to increased tectonic activity. Subsidence of the basin linked with uplift of the hinterland may have involved deposition of transgressive sediments within the period of time necessary for hinterland erosion. A major regressive phase with deposition of large amounts of newly eroded, coarse detritus succeeded the period of sedimentation of fines. Such a response to tectonic activity has been mentioned by Rust (1979).

From section I to II increasing thickness is combined with decreasing quantities of sandstone and gravel. This may very well have been caused by synsedimentary tectonic activity. Another relation of sedimentation pattern and tectonics is found close to the northwest directed joints in the southern tributary valley. Southwest and northwest directed faults are parallel to the primary and secondary (maximally deflected) palaeocurrent directions, respectively.

The deposits described in detail constitute the base of the sections. A conglomeratic sheet is split up into several lenses in a mud matrix (Fig. 15). The sediments were formed at the mouth of a shallow, braided river during a single fan-delta progradation process. The braided stream made up a part of a small alluvial system, several of which fringed the rising Central Pyrenees. The exposed deposits represented in Fig. 14 belonged to another system situated to the west. The systems transported detritus from the mountain chain to an elongated marine basin. At the time of deposition the eastern termination of the basin was situated in the vicinity of Puente de Montañana. The climate was tropical with marked dry and wet periods (Van der Meulen, 1982).

Wescott and Etheridge (1980) described two fan-delta types, representing end 
$\mathrm{N}$

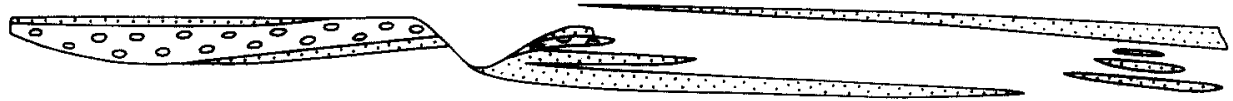

Fig. 15. A generalised N-S section through the investigated interval showing the morphologies of the conglomerate and the sandstone facies.

members of a spectrum. In this case we are dealing with the end member; more completely developed, subaerial fans that prograde into shallow marine water bodies. In contrast, the other end member comprises truncated subaerial fans that prograde onto relatively steep submarine slopes. The description of a Pliocene fan-delta from southeast Spain by Postma (1983) seems to agree with this model.

\section{CONCLUSIONS}

The sedimentary relief, inflow conditions and sediment movement in an Eocene transitional fan-delta environment have been reconstructed. The study of three-dimensionally exposed deposits was the basis of the reconstructions. Inflow took place from a shallow, braided stream. The low sedimentary relief allowed for jetflow from orifices of limited extent, which involved the formation of interconnected or separated lobes. Tabular cross-bedding and parallel lamination are the main sedimentary structures. Large-scale climbing bed forms indicate rapid sedimentation.

A large range of grain sizes (including gravel) is found in the shallow, braided channels. The sediment was transported by highly-energetic flow during high discharge periods. Inflow models for the deltaic environment cannot be applied, because of very high flow energy, the large range of grain sizes and the availability of large amounts of sediment. After comparison with a model of recent highly energetic inflow, the following interpretation of inflow hydrodynamics and sediment movement was made:

(1) Gravel was deposited close to the orifice. Flow expansion and inertial forces caused the formation of Gilbert-type deltas with moderately inclined foreset faces. During abandonment stages, flow expansion led to a steeply inclined foreset face.

(2) Frictional and inertial forces were in variable degree responsible for flow deceleration; this caused sand and mud sedimentation on a flat slope or in scour pits.

(3) Backsets formed due to expansion and frictional forces.

Gravel graded to sand downwards over the moderately inclined fan-delta face. Therefore a coarsening-upwards sequence of proximal deposits developed during progradation. In the course of progradation, large amounts of sand and mud were deposited in front of the fan-delta. After a phase of deep incision of these deposits, gravel supply diminished and aggradation of the stream channel took place. Large 
amounts of mud were deposited in front of the fan-delta face. The extent of incised sand lobes decreases upwards and therefore fining-upwards sequences are found in the distal parts. The top of the sequences is formed by a thin, alluvial fining-upwards sequence. Aggradation exceeded initial water depth.

The deposits originated in the transition zone of a fan-delta, where the distal parts of a wide, braided system contacted a restricted part of a marine basin. The basin was elongated in a direction perpendicular to the main alluvial palaeocurrent direction and therefore deflection of the inflow could take place. There was no reworking by marine agents. Only during periods of accelerated tectonic activity major amounts of gravel were deposited in the transition zone. There was then a rapid regression of the marine environment.

\section{ACKNOWLEDGEMENTS}

The fieldwork was accomplished in 1981 with a grant from the Stichting Molengraaf Fonds. This study forms an extension of the research carried out in the scope of a M.Sc. Thesis. Members of the drafting office of the geological institute prepared the figures. Anonymous reviewers made helpful comments on the first draft of the manuscript. Comparative Sedimentology Research Group, Rep. No. 19B.

\section{REFERENCES}

Bates, C.C., 1953. Rational theory of delta formation. Bull. Am. Assoc. Pet. Geol., 37: 2119-2162.

Buurman, P., 1980. Palaeosols in the Reading Beds (Palaeocene) of the Alum Bay, Isle of Wight, U.K. Sedimentology, 27: 593-606.

Davis, W.M., 1890. Structure and origin of glacial sand plains. Geol. Soc. Am. Bull., 1: 195-202.

Farquharson, G.W., 1982. Lacustrine deltas in a Mesozoic alluvial sequence from Camp Hill, Antarctica. Sedimentology, 29: 717-726.

Jopling, A.V. and Richardson, E.V., 1966. Backset bedding developed in shooting flow in laboratory experiments. J. Sediment. Petrol., 36: 821-825.

McBride, E.F., 1962. Flysch and associated beds of the Martinsburg Formation, Ordovician, Central Appalachians. J. Sediment. Petrol., 32: 39-91.

McGee, W.J., 1897. Sheetflood erosion. Geol. Soc. Am. Bull., 8: 87-112.

McGowen, J.H., 1970. Gum Hollow fan-delta, Nueces Bay, Texas. Bur. Ecol. Geol., Rep. Inv., pp. 1-91.

Middleton, G.V. and Hampton, M.A., 1976. Subaqueous sediment transport and deposition by sediment gravity flows. In: D.J. Stanley and D.J.P. Swift (Editors), Marine Transport and Environmental Management. John Wiley, New York, N.Y., pp. 197-218.

Nijman, W., 1981. Fluvial sedimentology and basin architecture of the Eocene Montañana Group, South Pyrenean Tremp-Graus Basin. In: T. Elliot (Editor), Fieldguide International Fluvial Congress Keele, Vol. 4, Univ. of Keele, pp. 1-27.

Nijman, W., and Nio, S.D., 1975. The Eocene Montañana delta. In: The sedimentary Evolution of the Palaeogene South Pyrenean Basin-Guide Book of Excursion 19. IXth Cong. Sediment. (Nice), 56 pp.

Postma, G., 1983. Water escape structures in the context of a depositional model of a mass flow dominated conglomeratic fan-delta (Abrioja Formation, Pliocene, Almeria Basin, SE Spain). Sedimentology, 30: 91-104. 
Puigdefabregas, C. and Van Vliet, A., 1978. Meandering stream deposits from the Tertiary of the Southern Central Pyrenees. In: A. Miall (Editor), Fluvial Sedimentology. Can. Soc. Pet. Geol., Mem. 5, Calgary, Alta., pp. 469-485.

Rachocki, A., 1981. Alluvial Fans An Attempt at An Empirical Approach. Wiley, Chichester, $161 \mathrm{pp}$. Rust, B.R., 1979. Coarse alluvial deposits. In: R.G. Walker (Editor), Facies Models. Geol. Assoc. Can., Waterloo, Ont., pp. 9-21.

Sneh, A., 1979. Late Pleistocene fan-deltas along the Dead Sea Rift. J. Sediment. Petrol., 49: 541-552. Van der Meulen, S., 1982. Sedimentary facies and setting of Eocene point bar deposits, S. Pyrenees, Spain. Geol. Mijnbouw, 61: 217-228.

Van Eden, J.G., 1970. A reconnaissance of deltaic environment in the Middle Eocene of the Southern Central Pyrenees, Spain. Geol. Mijnbouw, 49: 145-157.

Wescott, A.W. and Ethridge, F.G., 1980. Fan-delta sedimentology and tectonic setting-Yallahs Fan-Deita, SE Jamaica. Bull. Am. Assoc. Pet. Geol., 64: 374-399.

Wright, L.D., 1977. Sediment transport and deposition at rivermouths: a synthesis. Bull. Geol. Soc. Am., 88: 857-868.

Wright, L.D. and Coleman, J.M., 1974. Missippi rivermouth processes: Effluent dynamics and morphologic development. J. Geol., 82: 751-778. 